\title{
Az áttétes kasztrációrezisztens prosztatarák gyógyszer-rezisztenciájának molekuláris vonatkozásai
}

\author{
Szarvas Tibor dr. ${ }^{1,2^{*}}$ - Csizmarik Anita ${ }^{1^{*}}$ - Nagy Nikolett ${ }^{1}$ \\ Keresztes Dávid ${ }^{1}$ - Váradi Melinda ${ }^{1}$ - Küronya Zsófia dr. ${ }^{3}$ \\ Riesz Péter dr. ${ }^{1}$ - Nyirády Péter dr. ${ }^{1}$ \\ ${ }^{1}$ Semmelweis Egyetem, Általános Orvostudományi Kar, Urológiai Klinika, Budapest \\ ${ }^{2}$ Duisburg-Esseni Egyetem, Urológiai Klinika, Essen \\ ${ }^{3}$ Országos Onkológiai Intézet, Urogenitális Tumorok és Klinikai Farmakológiai Osztály, Budapest
}

\begin{abstract}
A metasztatikus kasztrációrezisztens prosztatarák kezelésére az elmúlt években számos új, különböző hatásmechanizmusú gyógyszeres kezelés vált elérhetővé. Ez a fejlődés a terápiás döntéshozatalt egyre nehezebbé teszi. Az újabb kezelésekkel szemben is megfigyelhető az alapvonali, a szerzett és a keresztrezisztencia jelensége is. Ezért tehát az elsődleges terápia helyes megválasztása mellett, az azt követő vonalakban alkalmazott kezelések sorrendje és alkalmazásuk ideje is optimalizálásra szorul. Az újabb kezelésekkel kapcsolatos rezisztenciamechanizmusok egyre nagyobb mértékben válnak ismertté. Ezzel a terápiatervezés az eddigi empirikus - fóleg a kipróbálásra építő - irányából egyre inkább a racionális - az adott daganat molekuláris sajátságait is figyelembe vevő -, személyre szabott kezelés irányába mozdul el. Ebben az összefoglaló közleményben ismertetjük azokat a rezisztenciamechanizmusokat, amelyek a metasztatikus kasztrációrezisztens prosztatarák kezelésében leggyakrabban használt három gyógyszerrel - docetaxel, abirateron és enzalutamid - kapcsolatosak. Többek között áttekintést nyújtunk a MDR- (multidrogrezisztens) fehérjéken keresztül megvalósuló, az androgénreceptor-, a Wnt-, a p53-szignálút, valamint a DNS hibajavító mechanizmusában részt vevő gének (mint például a $B R C A$ és $A T M$ ) sérüléseivel összefüggésben kialakuló és a neuroendokrin differenciáció által kiváltott rezisztenciamechanizmusokról.
\end{abstract}

Orv Hetil. 2020; 161(20): 813-820.

Kulcsszavak: kasztrációrezisztens prosztatarák, terápiarezisztencia, docetaxel, enzalutamid, abirateron

\section{Molecular underpinnings of systemic treatment resistance in metastatic castration-resistant prostate cancer}

In the last few years, several new drugs with various mechanisms of action have been approved for the treatment of castration-resistant prostate cancer. Due to this development, therapeutic decision-making has become increasingly complex. Therefore, therapy selection as well as timing and sequence of treatments need to be optimized in an individual manner. In addition, also for these novel therapies, baseline and acquired as well as cross-resistance have been observed. Underlying mechanisms become increasingly clear, resulting in a shift from empiric-based towards rational-based therapeutic decision-making. In the present review, we provide an overview on the resistance mechanisms against the most frequently applied systemic treatments of metastatic castration-resistant prostate cancer such as docetaxel, abiraterone and enzalutamide. We summarize - among others - the mechanisms by MDR (multidrugresistant) protein expression, alterations of androgen receptor, Wnt, p53 and DNA-repair pathways (BRCA/ATM) as well as resistance through therapy-induced neuroendocrine differentiation of the tumour.

Keywords: castration-resistant prostate cancer, therapy resistance, docetaxel, enzalutamide, abiraterone

Szarvas T, Csizmarik A, Nagy N, Keresztes D, Váradi M, Küronya Zs, Riesz P, Nyirády P. [Molecular underpinnings of systemic treatment resistance in metastatic castration-resistant prostate cancer]. Orv Hetil. 2020; 161(20): 813820 .

(Beérkezett: 2020. január 22.; elfogadva: 2020. február 13.)

*A két szerző egyenlő mértékben járult hozzá a cikk megszületéséhez. 


\section{Rövidítések}

$\mathrm{ABCB} 1=(\mathrm{ATP}$-binding cassette sub-family B member $\mathrm{l}) \mathrm{az}$ ATP-kötő kazetta B alcsaládjának l-es tagja; $\mathrm{ABI}=$ abirateron; $\mathrm{APC}=$ adenomatosus polyposis coli; $\mathrm{AR}=$ androgénreceptor; $\mathrm{AR}-\mathrm{V7}=\mathrm{az}$ androgénreceptor 7-es variánsa; ATM = ataxia telangiectasia mutált; ATP $=($ adenosine triphosphate $)$ adenozin-trifoszfát; BRCA2 = (breast cancer type 2 ) az emlörákra hajlamosító gén 2 -es típusa; $\mathrm{CCNDl}=$ ciklin $\mathrm{Dl} ; \mathrm{CDK} 4 / 6=$ ciklindependens kináz-4-6; CgA = (chromogranin A) kromogranin $\mathrm{A} ; \mathrm{CRPC}=($ castration-resistant prostate cancer $)$ kasztrációrezisztens prosztatarák; $\mathrm{CTNNBl}=(\beta$-catenin $) \beta$-katenin; CYP17 = (cytochrome P450-17) citokróm P450-17; DBD = (DNA-binding domain) DNS-kötő domén; DHT = dihidrotesztoszteron; DKKI = dickkopf- $1 ; \mathrm{dMMR}=($ deficient mismatch repair) mismatch repair deficientia; DNA/DNS $=($ deoxyribonucleic acid) dezoxiribonukleinsav; DOC = docetaxel; ENZA = enzalutamid; ERG = (ETS-related gene $)$ ETS-kapcsolt gén; FDA $=$ (U.S. Food and Drug Administration) az Amerikai Egyesült Államok Élelmiszer-biztonsági és Gyógyszerészeti Hivatala; GR = glükokortikoidreceptor; IL = interleukin; KLK3 = kallikrein-3; LDB = (ligand-binding domain) ligandkötő domén; mCRPC $=$ (metastatic castration-resistant prostate cancer) metasztatikus kasztrációrezisztens prosztatarák; $\mathrm{MDR}=$ multidrog-rezisztens; $\mathrm{MIC}-1=($ macrophage inhibitory cytokine-1) makrofággátló citokin-1; MMP-7 = mátrixmetalloproteináz-7; mRNS = (messenger) hírvivő ribonukleinsav; MSI-high = magas szintü mikroszatellita-instabilitás; NAMPT $=($ nicotinamide phosphoribosyltransferase $)$ nikotinamid-foszforiboszil-transzferáz; NED $=$ (neuroendocrine differentiation) neuroendokrin differenciáció; NSE = neuronspecifikus enoláz; PARP $=$ poli $($ ADP-ribóz $)$ polimeráz; $\mathrm{PD}-1=$ (programmed cell death protein 1) programozott sejthalál fehérje- $1 ; \mathrm{PD}-\mathrm{Ll}=\mathrm{PD}$-ligand $1 ; \mathrm{PSA}=$ (prostate-specific antigen) prosztataspecifikus antigén; RECIST $=$ (response evaluation criteria in solid tumors) a válasz értékelésének kritériumai a nem a „vérsejtekből” eredő daganatokban; RNF43 = (ring finger protein 43 ) gyürüsujjfehérje-43; SOST = szklerosztin; TMPRSS $2=($ transmembrane protease, serine 2$)$ transzmembrán szerin-proteáz-2; TP53 = tumorprotein p53; WIF1 = Wnt-gátló faktor- 1 ; Wnt $=$ wingless $/$ integrated

A lokálisan előrehaladott és/vagy metasztatikus prosztatarák kezelésére az androgéndeprivatiós terápia kezdetben hatékonyan alkalmazható. Ebben a hormonérzékeny stádiumban a tesztoszteronszint sebészi vagy gyógyszeres csökkentésével (kasztráció) kezdetben látványos biokémiai (szérum-PSA-csökkenés), illetve radiológiai (tumorméret-csökkenés) választ lehet elérni, mellyel párhuzamosan gyakran a betegek tünetei is javulást mutatnak. Jellemző́n azonban 2 év elteltével szinte minden esetben kialakul a kasztrációrezisztens állapot (CRPC). Ezen állapotról akkor beszélünk, ha a kasztrációs tesztoszteronszint $(1,7 \mathrm{nmol} / \mathrm{l}$ vagy $50 \mathrm{ng} / \mathrm{dl})$ ellenére emelkedő szérum-PSA-koncentráció figyelhető meg (mely legalább 50\%-kal meghaladja a kezelés során elért legalacsonyabb szintet), vagy pedig radiológiai progreszszió alakul ki (legalább két vagy több új csontmetasztázis jelenik meg, vagy a lágyrész-áttét RECIST-kritériumok szerint progrediál) [1]. Emellett előfordulhat a tünetekben megmutatkozó állapotromlás, mely azonban PSA-, illetve radiológiai progresszió nélkül nem jelent kasztrációrezisztens állapotot. A metasztatikus CRPC (mCRPC) kezelésében 2004-től alkalmazható a docetaxel (DOC), mely mindmáig az egyik legfontosabb első vonalbeli kezelés [2]. A mCRPC kezelésének terápiás lehetőségei az elmúlt években dinamikus ütemben növekedtek. A DOC-rezisztens betegek számára elérhetôvé vált a kabazitaxel, valamint megjelent két újgenerációs, androgén támadáspontú kezelés: az abirateron (ABI) és az enzalutamid (ENZA). Megjelent továbbá egy, a csontmetasztázisok kezelésére kifejlesztett alfa-sugárzó izotóp, az alfaradin, valamint a sipuleucel-T rákvakcina. Az ezen szerekkel való optimális kezelési szekvencia helyes megválasztása sokszor nagy kihívás elé állítja mind a klinikusokat, mind pedig a betegeket, ezért számos kutatás irányul olyan molekuláris markerek azonosítására, melyek támpontként szolgálhatnak a terápiás döntések helyes megválasztásához. A gyógyszeres kezeléssel kapcsolatos nehézségek sorát tovább gyarapítja a hatóanyagokkal szembeni primer vagy szerzett, valamint az úgynevezett keresztrezisztencia is.

\section{Docetaxel}

A docetaxel (DOC) a mikrotubulusokat felépítő tubulinmolekula béta-alegységeihez kötódik, ezáltal stabilizálja a sejtvázat, mely a sejten belüli „bénuláshoz” vezet. Ez a bénulás a sejtosztódás során a mitotikus húzófonalak gátlásán keresztül megakasztja a tumorsejtek osztódását, így a folyamat leáll a sejtciklus G2/M ellenőrző pontján, és a sejt apoptózis következtében elpusztul [3].

\section{Transzportfehérjék}

A MDR-gének (más néven ABC-transzporterek) pumpafehérjéket kódolnak, melyek a tumorsejtek membránjában elhelyezkedve képesek a gyógyszermolekulákat a sejtből kipumpálni [4]. DOC használatakor a tumorsejtek felszínén megjelenő pumpafehérjék mennyisége megsokszorozódik, csökkentve a kezelés hatásfokát [4]. A kabazitaxel egy, a DOC-hez hasonlóan mikrotubulusgátló kemoterápia, melyet DOC-rezisztens mCRPC-betegek számára fejlesztettek ki. A kabazitaxel azért hatékony DOC-rezisztens betegekben, mert a pumpafehérjék kisebb hatékonysággal tudják kipumpálni a tumorsejtből, mint a docetaxelt [5]. Megfigyelték, hogy a DOCrezisztens betegek szérummintáiból kinyert exoszómák több ABCBl-pumpafehérjét tartalmaznak a DOC-re érzékeny betegekhez képest. Ez alapján a vérből vagy akár vizeletből kinyerhető exoszómák $\mathrm{ABCBI}$-szintjének meghatározása segítséget nyújthat a DOC-terápia hatékonyságának előrejelzésében [6]. 


\section{ERG}

Az ERG transzkripciós faktor fokozott termelődése a prosztatadaganatok több mint felében megfigyelhető. Ennek hátterében többnyire az ERG és TMPRSS2 gének között létrejövő kóros fúzió áll [7]. Galletti és mtsai kimutatták, hogy az említett ERG emelkedett expressziója összefüggést mutat a prosztatarák csökkent DOC-érzékenységével, így az ERG-pozitív prosztatadaganatok kétszer nagyobb eséllyel válnak rezisztenssé DOC-re, mint az ERG-negatív tumorok [8]. Ezzel összhangban áll az a megfigyelés, mely szerint a TMPRSS2-ERG pozitív betegek alacsonyabb PSA-válasszal és rövidebb PSA-progreszszió-mentes túléléssel reagáltak a DOC-kezelésre, mint az ezen génfúziót nem hordozó betegek [9]. Érdekes módon azonban a hormonérzékeny metasztatikus prosztatarákos betegek esetében két független kutatócsoport is ennek az ellenkezőjét állapította meg. Küronya és mtsai 50, míg Rajpar és mtsai összesen 334, hormonérzékeny metasztatikus prosztatarákos beteg szövetmintának vizsgálatával egybehangzóan arra a következtetésre jutottak, hogy a pozitív ERG-immunfestődés a DOC-kezelés alatti jobb relapsusmentes túléléssel korrelál $[10,11]$. Ezek alapján tehát azt mondhatjuk, hogy az ERG-expresszió DOC-rezisztenciában betöltött esetleges biomarker szerepének tisztázására további vizsgálatok szükségesek.

\section{Citokinek}

A prosztatarákot gyakran kísérik gyulladásos folyamatok. A tumorsejtek és a környezetükben lévő myeloid sejtek között citokinmolekulákon keresztül megvalósuló kölcsönhatás szerepet játszik a terápiarezisztenciák kialakulásában $[12,13]$. A citokinek közül az interleukin-6 (IL6) emelkedett szérumszintje mutatott összefüggést a DOC-kezelésre adott gyengébb terápiás válasszal [12].

Mahon és mtsai 28-féle citokin szintjét vizsgálták 55 DOC-kezelt CRPC-betegnek a terápia különböző időpontjaiban gyüjtött vérmintáiban, amelyeket a betegek PSA-válaszával vetettek össze. Ennek eredményeképpen az IL-4, az IL-6 és a MIC-1 biomarkerként történő alkalmazását találták ígéretesnek [12]. Ezenfelül egy további gyulladásos mediátor, az YKL-40 szérumszintjei is összefüggést mutattak a DOC-kezelés alatti rövidebb túléléssel [14]. Kutatócsoportunk számos lehetséges szérumbiomarker vizsgálata során az MMP-7 [15], a sindecan-1 [16] és a NAMPT [17] DOC-kezelés előtti emelkedett koncentrációival kapcsolatban talált összefüggést a gyengébb terápiás válasszal és a rövidebb túléléssel.

\section{Abirateron és enzalutamid}

Az újgenerációs, antiandrogén támadáspontú gyógyszerek közül elsőként az abirateront (ABI), majd ezt követően az enzalutamidot (ENZA) törzskönyvezték olyan, mCRPC-ban szenvedő betegek kezelésére, akik a DOCkemoterápia mellett vagy azt követően progrediáltak
$[18,19]$. Az ABI egy szelektív CYP17Al-enzim-blokkoló, mely a sejtek androgén-bioszintézisének gátlásán keresztül csökkenti az endogén tesztoszteronszintet [18]. Az ENZA pedig egy androgénreceptor (AR)-antagonista, mely hármas hatással rendelkezik: egyrészt kompetitív antagonistaként gátolja a receptor-ligand (dihidrotesztoszteron [DHT]) kötődés létrejöttét, másrészt gátolja a receptor-ligand-komplex sejtmagba jutását (nukleáris transzlokációját), valamint az AR DNS-hez való kötődését is [19].

\section{Androgénreceptor amplifikáció/overexpresszió}

$\mathrm{Az}$ androgénreceptor (AR) génjének amplifikációja, valamint ennek következtében az AR-fehérje fokozott termelődése fontos szerepet játszik az újgenerációs antiandrogén terápiák elleni rezisztencia kialakulásában. ENZA- és ABI-kezelt mCRPC-betegek szérum- és plazmamintájában is gyakran ( 30\%) kimutatható az AR amplifikációja vagy túltermelődése $[20,21]$. Ez a jelenség érdekes módon kifejezettebb formában alakul ki az ENZA-, mint az ABI-kezelés kapcsán. Több független vizsgálatban is kimutatták, hogy az AR eltéréseit (amplifikáció, mutáció) hordozó betegek esetében rövidebb idő alatt alakult ki a radiológiai, illetve a klinikai progresszió is [20-22]. Az újgenerációs, antiandrogén támadáspontú gyógyszerek elleni rezisztencia kialakulásában szerepet játszhat még a CYP17 fokozott termelődése is $[23,24]$.

\section{Androgénreceptor-mutáció}

Az AR-génben létrejövő pontmutációk is felelősek lehetnek az ENZA- és az ABI-rezisztencia kialakulásáért (1. ábra). Az AR-antagonisták - úgymint az ENZA - a hatásukat többek között az AR ligandkötő doménjének gátlásán keresztül fejtik ki. Az AR-ban kialakuló rezisztenciamutációk többnyire a receptornak a ligandkötésért felelős részében alakulnak ki, és annak szerkezetét olyan módon változtatják meg, hogy a receptor ligandkötő specificitása csökken. Ez azt jelenti, hogy a receptort már nemcsak a fiziológiás körülmények között aktiváló androgén hormon - a DHT -, hanem számos egyéb, fiziológiásan is jelen lévő, illetve gyógyszermolekula is aktiválni tudja, ami az AR fokozott aktivitásához és ezáltal a prosztatadaganat további növekedéséhez vezet [20, 25-27].

Az AR eltérései az első vonalban ABI- és ENZA-kezelést kapó betegekben 5-17\%-ban, míg az ezeket másodvonalban (DOC után) kapó betegekben 30-40\%-ban fordulnak elő, és jelenlétük összefüggést mutat a terápiára adott rosszabb válasszal és a rövidebb túléléssel.

\section{Az androgénreceptor splice-variánsa}

Az ENZA- és az ABI-rezisztencia kialakulását a leggyakrabban az AR-gén egyik hibás, úgynevezett splice-variánsa, az AR-V7 jelenlétével hozták összefüggésbe. Az 
AR-V7 egy olyan AR-fehérjét kódol, melyből hiányzik a ligandkötő domén, így a receptor ligand kötődése nélkül is aktív (1. ábra) [28].

Az AR-V7-nek az ABI- és ENZA-kezelésre vonatkozó prediktív értékét vizsgáló első tanulmány vérből izolált keringő tumorsejtekben mRNS-szinten vizsgálta az ARV7 jelenlétét. A kezelés előtti mintákban a betegek 29\%ánál lehetett AR-V7-pozitív keringő tumorsejteket kimutatni, s e betegek közül egy sem adott PSA-választ a kezelésre. Ezzel szemben az AR-V7-negatív betegek 61\%-a adott választ a terápiára. Hasonlóképpen a progressziómentes túlélés is rövidebb volt az AR-V7-pozitív betegeknél, mind az ENZA- (2,1 vs. 6,1 hónap), mind pedig az ABI-kezeltek csoportjában (2,3 vs. 6,3 hónap) [28]. Egy másik vizsgálatban ugyancsak a keringő tumorsejtek AR-V7-tartalmát vizsgálták, de ezúttal nem RNS-szinten, hanem fehérjeszinten immunhisztokémiával, amely a hibás AR-V7 fehérje mennyiségén kívül annak a sejten belüli lokalizációját is megítélhetővé teszi. Azt találták, hogy nem csupán az AR-V7 jelenléte és mennyisége, de annak sejten belüli elhelyezkedése is értékes információt szolgáltathat a terápia hatékonyságának előrejelzéséhez [29].

A túlnyomórészt pozitív eredmények mellett két tanulmány is beszámolt arról, hogy az AR-variánsok jelenléte nem feltétlenül jelzi előre az újgenerációs antiandrogén terápiák hatékonyságát [30, 31$]$.

A kereskedelmi forgalomban két módszer: az „AdnaTest” és az „EPIC Sciences” terjedt el. Mindkét módszerrel egyöntetúen rövidebb progressziómentes és teljes túlélést mértek az AR-V7-pozitív betegeknél [32]. $\mathrm{Az}$ AdnaTest a keringő tumorsejteket három specifikus antitest segítségével szeparálja a vérből, majd real-time (valós idejü) PCR-vizsgálattal detektálja az AR-V7 jelenlétét. Ezzel szemben az EPIC Sciences módszere vérkeneten immunfluoreszcens módszerrel azonosítja a keringő tumorsejteket és az AR-V7 jelenlétét is. Ezenfelül megkülönbözteti a magi és a sejtplazmában található AR-V7-lokalizációt is. A két módszer közvetlen összehasonlítása rávilágított arra, hogy mind a vizsgálat prediktív értéke, mind pedig a pozitívnak talált esetek száma nagyban függ a megválasztott módszer minőségétől, ami egyben magyarázatul is szolgálhat a korábban idézett két, a többinek ellentmondó vizsgálat negatív eredményeire is.

Összességében tehát elmondható, hogy az AR-V7 a betegek 10-30\%-ában van jelen, és az ABI-, valamint az ENZA-kezelés tekintetében prediktív értékkel bír. Az AR-V7-pozitív betegek a DOC-kezelésre érzékenyebben reagálnak. A kimutatásra alkalmazott módszer befolyásolja a pozitív esetek arányát. A jelenlegi terápiás lehetôségek mellett az a módszer tünik a legalkalmasabbnak, amelyik a legkevesebb beteget találja hibás módon terápiarezisztensnek (azaz amelyiknek a negatív prediktív értéke a legmagasabb). Ennek a kritériumnak a jelenleg hozzáférhető adatok tükrében az a módszer látszik a leginkább megfelelni, amelyik az AR-V7 sejten belüli lokalizációjának megítélését is lehetővé teszi.

\section{Glükokortikoidreceptor}

$\mathrm{Az}$ újgenerációs antiandrogén kezelésekre kialakuló rezisztencia létrejöhet a glükokortikoidreceptor (GR) aktivációja vagy fokozott termelődése által is. Kísérleti adatok arra utalnak, hogy a GR képes az ENZA-kezelés hatására gátolt AR-t megkerülve aktiválni az általa indukált géneket (KLK3, TMPRSS2) és így kialakítani az ENZA-rezisztenciát. Ezzel egybecsengenek azok a klinikai szövetmintákon kapott eredmények, melyek a magasabb GR-expressziót mutató betegeknél az ENZA-kezelésre gyorsabban kialakuló progressziót találtak [33].

Puhr és mtsai a GR szerepét az ABI elleni rezisztenciában vizsgálták. Azt találták, hogy a GR-inhibitornak az ABI-val történő együttes alkalmazása növeli annak terápiás hatását. Kimutatták továbbá, hogy a GR emelkedett expressziója az antiandrogén terápia következményeként jön létre, és szerepe van az androgén támadáspontú szerekkel szembeni rezisztencia kialakulásában, így a hosszú távon antiandrogén terápiával kezelt prosztatarákos betegekben a kettős, AR-t és GR-t célzó terápia hatásos lehet [34]. Eredményeik alapján a szteroid gyulladásgátlók AR-t célzó szerekkel történő együttes alkalmazásának hasznossága megkérdőjelezhető.

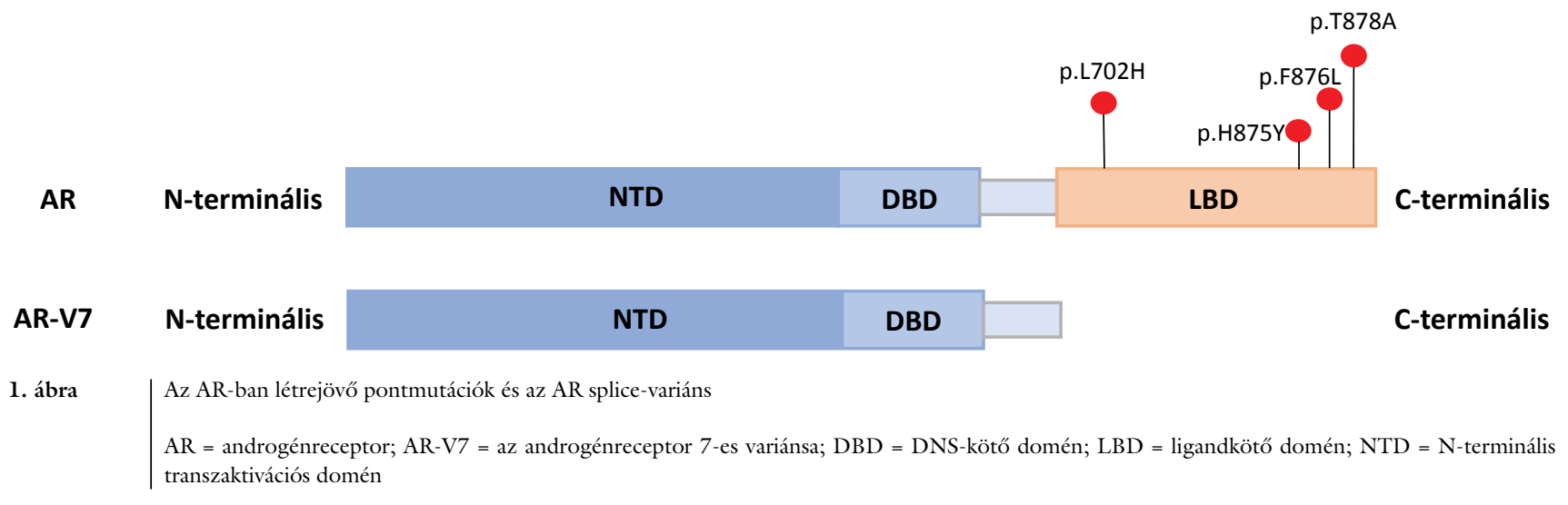




\section{BRCA- és ATM-mutációk}

Az újgenerációs antiandrogén terápiával szembeni rezisztencia összefüggésben lehet a homológ rekombinációban részt vevő $B R C A 2$ és $A T M$ gének szomatikus mutációival.

Egy nagy, retrospektív vizsgálat szerint azok a betegek, akik a homológ rekombináció génjeiben mutációt hordoznak, rosszabb választ adnak az ABI- vagy ENZA-kezelésre [35]. Az ezt követő prospektív kutatásba 202, metasztatikus kasztrációrezisztens prosztatarákos beteget választottak be, akiknél az első vonalban ABI- vagy ENZA-kezelést kezdtek, és a kezelés előtt 72 , tumorbiológiai szempontból jelentős gén szekvenálását végezték el. Összesen 14 betegnél detektáltak $B R C A 2$ - vagy $A T M$-mutációt. Az összes vizsgált klinikai és genetikai paraméter közül a BRCA2- és $A T M$ mutációk jelenléte bizonyult a legerősebb rizikófaktornak a progressziómentes túlélés tekintetében [27]. A homológ rekombinációs génjeikben sérülést hordozó betegek tehát gyengébb választ adnak az ABI- és ENZA-kezelésekre, ezért különösen fontosak azok a vizsgálatok, melyek azt bizonyították, hogy éppen ezekben az esetekben hatékonyabb a poli(ADP-ribóz)polimeráz (PARP)-inhibitorok, illetve a platinaalapú kemoterápia alkalmazása $[36,37]$.

\section{A sejtciklust szabályozó útvonal}

A sejtciklus szabályozásában részt vevő TP53-gén eltérései is összefüggésbe hozhatók az ENZA- vagy ABIrezisztencia kialakulásával. A korábban idézett, 202 mCRPC-beteget vizsgáló prospektív kutatásban 65 betegnél találtak eltérést a TP53-génben, s közülük 19 beteg esetében két vagy több eltérést is detektáltak. Ezek a betegek rövidebb idő alatt progrediáltak, mint a csupán egy TP53-mutációt hordozó betegek. Továbbá a TP53 szomatikus mutációt hordozó betegeknél a mutáció jelenléte összefüggésbe hozható az alapvonali rezisztencia jelenlétével [27]. A TP53-hibát hordozó sejtek támadására jelenleg több célzott terápiás szerrel is folynak klinikai vizsgálatok, melyek kifejezetten a hibás TP53-gént hordozó betegek esetében lehetnek hatásosak [38].

A TP53 mellett a sejtciklus szabályozásában szerepet játszó másik gén, a ciklin Dl (CCNDI) is részt vehet az újgenerációs antiandrogén kezelés során kialakuló rezisztencia kialakulásában. Megfigyelték, hogy az ENZAés ABI-rezisztens betegek keringő tumorsejtjeiben a CCNDl-gén expressziója szignifikánsan magasabb. Terápiás szempontból lényeges eredmény, hogy az ENZArezisztens és a CCNDl-et felülexpresszáló tumorsejtek a jelenleg az emlődaganatok kezelésében már alkalmazott CDK4/6-inhibitorokkal (palbociklib, ribociklib) célzottan elpusztíthatók [39].

\section{A Wnt-útvonal}

Egy 2017-ben publikált prospektív vizsgálatban 82, ABIkezelésnek alávetett beteg metasztatikus mintáin végeztek teljes exom-szekvenálást, majd 12 hét elteltével vizsgálva a biokémiai és radiológiai progressziót, azt találták, hogy a 32, ABI-rezisztens beteg mintáiban a Wnt/ $\beta$ katenin útvonal génjei mutálódtak a leggyakrabban. A kezelésre reagáló betegeknél a CTNNB1-gén 17\%-ban sérült, míg a rezisztens betegek esetében ez az arány $56 \%$ volt. Emellett a rezisztens betegekben a Wnt/B-katenin útvonal negatív regulátor génjei (WIFI, SOST és DKKI) is gyakrabban mutálódtak [40]. Egy további, retrospektív vizsgálatban, amelyben első vonalban ENZA-val vagy ABI-val kezelt mCRPC-betegek tumor-DNS-ében vizsgálták a Wnt-szignálút szabályozásában szerepet játszó géneket, azt találták, hogy a CTNNB1, APC és RNF43 gének eltéréseit hordozó betegek rövidebb teljes túlélésre és gyorsabb PSA-progresszióra számíthattak [41]. A jövőben azon betegek esetében, akiknél a Wnt-útvonal valamely meghatározó génje sérült, különböző célzott terápiás kezelések is szóba jöhetnek. Ilyen például a foxy-5, az LGK97 porcupininhibitor, illetve az ipafricept (OMP54F28) rekombináns fúziós fehérje [38].

\section{PD-Ll-termelődés}

A PD-Ll fokozott expressziója általi immunrendszermegkerülés is szerepet játszhat az ENZA-rezisztencia kialakulásában. Kimutatták, hogy azok a betegek, akik az ENZA-kezelés alatt progrediáltak, vérmintájukban szignifikánsan több PD-L1/2+ dendritikus sejtet tartalmaztak, azokhoz a betegekhez képest, akik válaszoltak a kezelésre [42]. Továbbá ezek az eredmények alátámasztják azt a preklinikai vizsgálatot, melyben az ENZA-rezisztens xenograft egereknél szignifikánsan több PD-L1/2+ dendritikus sejtet mutattak ki [42]. Jelenleg fázis 2 . klinikai vizsgálat alatt áll az anti-PD-1-inhibitor pembrolizumab olyan mCRPC-betegek esetében, akik ENZAkezelés alatt progrediáltak. A vizsgálat elsődleges eredményei biztatóak; az eddig beválasztott 28 mCRPCbeteg 18\%-a adott legalább 50\%-os PSA-választ, 25\%-a pedig radiológiai választ az anti-PD-1-kezelésre [43]. Itt kell megjegyezni, hogy az FDA 2017. évi engedélye alapján a pembrolizumab jelenleg adható az olyan inoperábilis vagy metasztatikus szolid tumorban, így prosztatarákban szenvedő betegeknek is, akik daganatának genetikai vizsgálata kifejezett mikroszatellita-instabilitást (MSIhigh) vagy mismatch repair deficientiát (dMMR) mutat, akiknél a korábbi terápia hatástalannak bizonyult, jó általános állapotúak, és nincs elérhető alternatív kezelés [44].

\section{Neuroendokrin prosztatarákok}

Bár a tisztán kissejtes, neuroendokrin szövettani megjelenésú prosztatarákok igen ritkák (<1\%), a legtöbb prosztata-adenocarcinoma gyakran tartalmaz elszórtan elhe- 
lyezkedő, neuroendokrin differenciációt (NED) mutató tumorsejteket. Ez utóbbiak az adenocarcinoma típusú tumorsejtekkel ellentétben nem termelnek PSA-t, és nem reagálnak az antiandrogén terápiára, aminek következtében az androgénmegvonásos kezelés alatt kiszelektálódnak, és a kasztrációrezisztens állapot elérésekor már jelentős arányban tartalmazhatnak agresszív növekedést mutató és terápiarezisztens neuroendokrin részeket. Ezek a terápia hatására nagy arányban neuroendokrinné váló prosztatadaganatok külön kategóriát alkotnak, melynek neve terápia által kiváltott kissejtes neuroendokrin prosztatarák (treatment-emergent small cell prostate cancer) [45]. A fenti szelekciót „neuroendokrin transzdifferenciáció"-nak is nevezik, mely a tumorsejtek számára az androgén támadáspontú szerek hatása előli menekülő útvonalat jelenti. Ezzel összhangban a neuroendokrin differenciáció szérummarkereinek - mint például a kromogranin $\mathrm{A}(\mathrm{CgA})$ és a neuronspecifikus enoláz (NSE) - emelkedett szintjei az ABI- és az ENZAkezelés csökkent hatékonyságával mutattak összefüggést [46]. A magas CgA- és NSE-szérumkoncentráció nagy érzékenységgel (bár viszonylag alacsony specificitással) jelzi a fenti átalakulást, ezért ezen markerek magas szintje esetén a daganatból vagy annak metasztázisából vett biopszia alapján megállapítható a terápia által kiváltott neuroendokrin prosztatarák jelenléte [47]. Egy újabb fázis 2. vizsgálat szerint az ilyen neuroendokrin sejtekben dúsult prosztatarákkal rendelkező betegek hosszabb progressziómentes túlélést mutattak, ha taxánkezelésüket karboplatinnal kombinálták [48].

\section{Következtetés}

Összességében a mCRPC-ban szenvedő betegek kezelésében egyre több gyógyszer válik elérhetôvé, melyek különböző mechanizmusokat célozva támadják a tumorsejteket. A prosztatarák mind klinikai, mind pedig molekuláris szempontból heterogén betegség. Az egyes kezelések hatékonyságában ennek megfelelően nagy különbségek mutatkoznak. A prosztatarák molekuláris hátterének egyre alaposabb feltérképezésével újabb és újabb rezisztenciamechanizmusok kerülnek azonosításra (2. ábra). A DOC esetében elsősorban a különböző pumpafehérjék megjelenése emelhető ki. Míg az újgenerációs antiandrogén kezelésekkel kapcsolatban az AR eltérései (pontmutációk, amplifikáció, illetve splice-variánsai) lényegesek, emellett újabban más mechanizmusok, mint a glükokortikoidreceptoron keresztüli, a homológ repair gének (BRCA, ATM) mutációihoz kötődő, a sejtciklus szabályozásában szerepet játszó (P53, CCNDl) vagy a Wnt-szignálút irányító génhibáinak szerepére derült fény. Ezeknek nem csupán az androgén támadáspontú kezelések előrejelzésében lehet jelentősége, hanem további potenciális terápiás utak azonosításában is. Így a BRCA/ATM mutációt hordozó betegek a PARPinhibitor-kezelésekból, a sejtciklusdefektussal rendelkező betegek a különböző CDK4/6-inhibitor-kezelések-

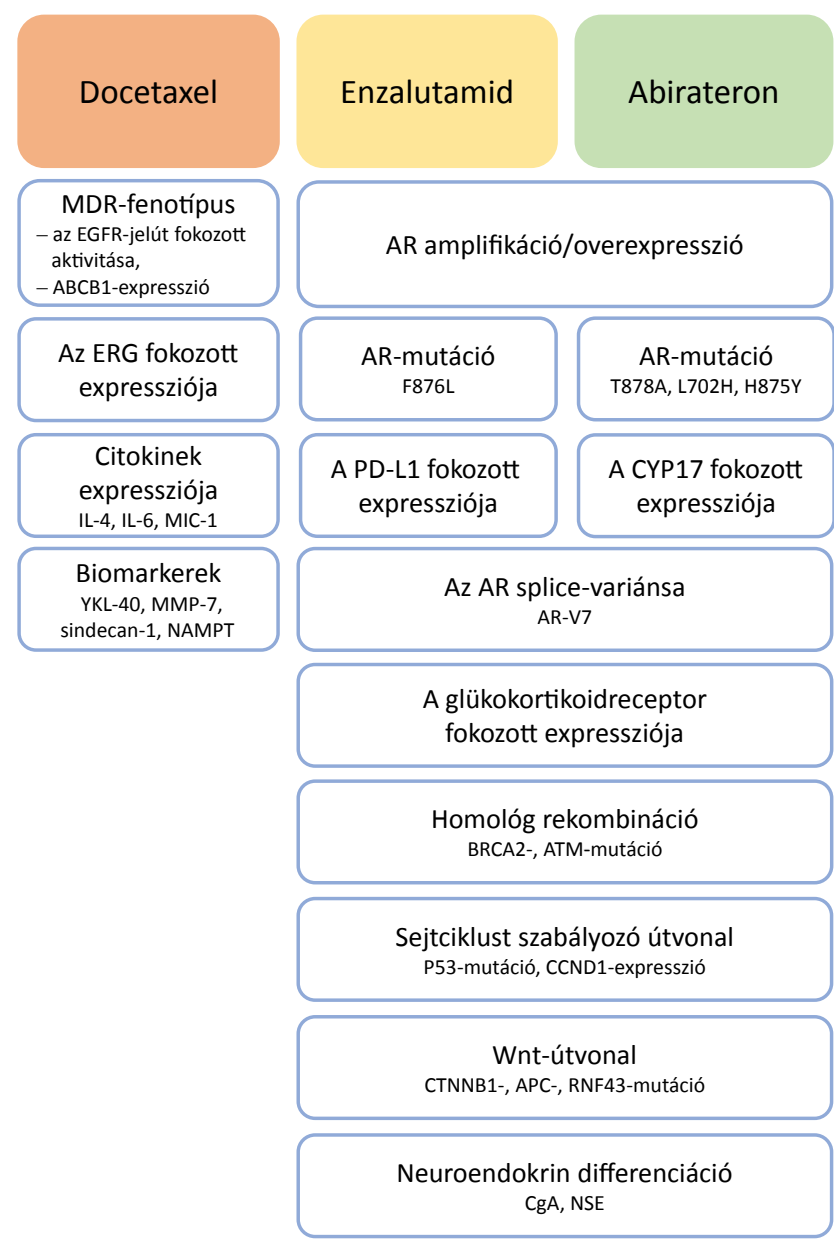

2. ábra

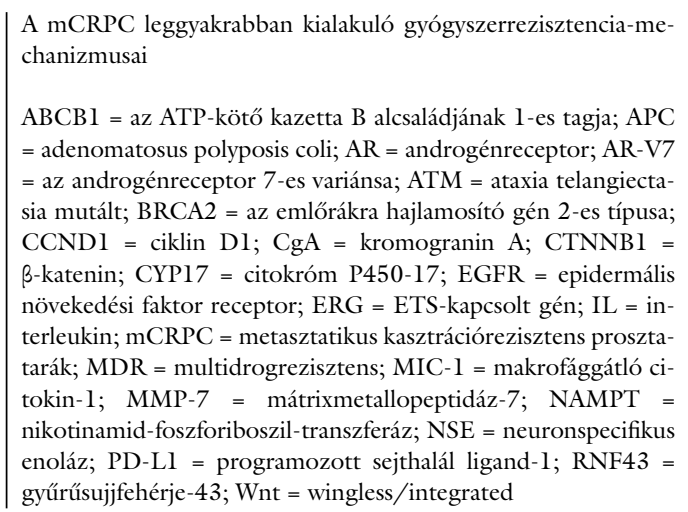

ből, míg a Wnt-szignálút sérüléseit hordozó betegek az új Wnt-inhibitor-kezelésektől várhatnak a jövőben kedvező hatást. Ezek alapján várható, hogy a molekuláris vizsgálatok elterjedésével egyre kifinomultabb terápiás döntéshozatali mechanizmusok válnak elérhetővé. A jelenlegi problémák között fontos megemlíteni, hogy a rezisztenciáért felelős legtöbb eltérés általában a betegeknek csak alacsony százalékában fordul elő, ezért hatásuk meggyőző, nagy esetszámot felsorakoztató igazolásához egyszerre igen sok beteg vizsgálatára van szükség. Ezzel együtt a rezisztenciában szerepet játszó eltérések száma egyre növekszik, így kevésbé egy-egy eltérés vizsgálatára, mint inkább különböző eltérések együttállásá- 
nak analízisére lesz szükség. Ezeknek a klinikai gyakorlatban történő elterjedését az is nehezíti, hogy egyes eltérések DNS-, más eltérések RNS- vagy fehérjeszinten vannak jelen, így nehéz egyetlen módszer alkalmazásával vizsgálódni. A komplex molekuláris vizsgálatok rutinszerü elterjedése iránt mutatkozó egyre szélesebb igény azonban minden bizonnyal kikényszeríti azokat a technikai fejlesztéseket, amelyek lehetővé teszik majd a fenti igények kielégítését.

Anyagi támogatás: A cikk az NKFIH (FK 12443), az NVKP (16-1-2016-004) és a Bolyai János Kutatási Ösztöndíj támogatásával készült.

Szerzői munkamegosztás: Sz. T.: A téma felvetése, a kézirat megírása, a kézirat javítása. Cs. A., N. N., K. D., V. M.: Irodalomkutatás, a kézirat megírása, összeállítása, az ábrák megrajzolása. K. Zs., R. P., Ny. P.: A kézirat véleményezése. A közlemény végleges változatát a szerzők elolvasták és jóváhagyták.

Érdekeltségek: A szerzóknek a jelen cikkel kapcsolatban nincsenek érdekeltségeik.

\section{Irodalom}

[1] Mottet N, Bergh RC, Briers E, et al. EAU-ESTRO-ESUR-SIOG Guidelines on prostate cancer. EAU guidelines. European Association of Urology, 2018.

[2] Cornford P, Bellmunt J, Bolla M, et al. EAU-ESTRO-SIOG Guidelines on prostate cancer. Part II: treatment of relapsing, metastatic, and castration-resistant prostate cancer. Eur Urol. 2017; 71: 630-642.

[3] Jordan M, Wilson L. Microtubules as a target for anticancer drugs. Nat Rev Cancer 2004; 4: 253-265.

[4] Szakács G, Paterson JK, Ludwig JA, et al. Targeting multidrug resistance in cancer. Nat Rev Drug Discov. 2006; 5: 219-234.

[5] Duran GE, Wang YC, Francisco EB, et al. Mechanisms of resistance to cabazitaxel. Mol Cancer Ther. 2015; 14: 193-201.

[6] Kato T, Mizutani K, Kameyama K, et al. Serum exosomal P-glycoprotein is a potential marker to diagnose docetaxel resistance and select a taxoid for patients with prostate cancer. Urol Oncol. 2015; 33: 385.e15-385.e20.

[7] Tomlins S, Rhodes DR, Perner S, et al. Recurrent fusion of TMPRSS2 and ETS transcription factor genes in prostate cancer. Science 2005; 310: 644-648.

[8] Galletti G, Matov A, Beltran H, et al. ERG induces taxane resistance in castration-resistant prostate cancer. Nat Commun. 2014; 5: 5548 .

[9] Reig Oे, Marín-Aguilera M, Carrera G, et al. TMPRSS2-ERG in blood and docetaxel resistance in metastatic castration-resistant prostate cancer. Eur Urol. 2016; 70: 709-713.

[10] Küronya Z, Sükösd F, Varga L. ERG expression can predict the outcome of docetaxel combined with androgen deprivation therapy in metastatic hormone-sensitive prostate cancer. Urol Oncol. 2019; 37: 289.el-289.e9.

[11] Rajpar S, Carmel AC, Merabet Z, et al. The benefit of combining docetaxel to androgen deprivation therapy in localized and metastatic castration-sensitive prostate cancer as predicted by ERG status: an analysis of two GETUG phase III trials. J Clin Oncol. 2017; 35(15 Suppl): 5012.
[12] Mahon KL, Lin HM, Castillo L, et al. Cytokine profiling of docetaxel-resistant castration-resistant prostate cancer. $\mathrm{Br} \mathrm{J}$ Cancer 2015; 112: 1340-1348.

[13] Balkwill F. Cancer and the chemokine network. Nat Rev Cancer 2004; 4: 540-550.

[14] Darr C, Krafft U, Hadaschik B, et al. The role of YKL-40 in predicting resistance to docetaxel chemotherapy in prostate cancer. Urol Int. 2018; 101: 65-73.

[15] Szarvas T, Sevcenco S, Módos O, et al. Matrix metalloproteinase 7 , soluble Fas and Fas ligand serum levels for predicting docetaxel resistance and survival in castration-resistant prostate cancer. BJU Int. 2018; 122: 695-704.

[16] Szarvas T, Sevcenco S, Módos O, et al. Circulating syndecan- 1 is associated with chemotherapy-resistance in castration-resistant prostate cancer. Urol Oncol. 2018; 36: 312.e9-312.e15.

[17] Keresztes D, Módos O, Szúcs M, et al. Comparative proteome analysis identified NAMPT as a potential serum marker for the prediction of docetaxel-resistance in prostate cancer. Eur Urol Suppl. 2019; 18: e482.

[18] de Bono JS, Logothetis CJ, Molina A, et al. Abiraterone and increased survival in metastatic prostate cancer. N Engl J Med. 2011; 364: 1995-2005.

[19] Scher HI, Fizazi K, Saad F, et al. Increased survival with enzalutamide in prostate cancer after chemotherapy. N Engl J Med. 2012; 367: 1187-1197.

[20] Azad AA, Volik SV, Wyatt AW, et al. Androgen receptor gene aberrations in circulating cell-free DNA: biomarkers of therapeutic resistance in castration-resistant prostate cancer. Clin Cancer Res. 2015; 21: 2315-2324.

[21] Conteduca V, Wetterskog D, Sharabiani MT, et al. Androgen receptor gene status in plasma DNA associates with worse outcome on enzalutamide or abiraterone for castration-resistant prostate cancer: a multi-institution correlative biomarker study. Ann Oncol. 2017; 28: 1508-1516.

[22] Wyatt AW, Azad AA, Volik SV, et al. Genomic alterations in cellfree DNA and enzalutamide resistance in castration-resistant prostate cancer. JAMA Oncol. 2016; 2: 1598-1606.

[23] Salvi S, Casadio V, Conteduca V, et al. Circulating cell-free $A R$ and CYPI7AI copy number variations may associate with outcome of metastatic castration-resistant prostate cancer patients treated with abiraterone. Br J Cancer 2015; 112: 1717-1724.

[24] Sharifi N, McPhaul MJ, Auchus RJ. "Getting from here to there" - mechanisms and limitations to the activation of the androgen receptor in castration-resistant prostate cancer. J Investig Med. 2010; 58: 938-944.

[25] Steketee K, Timmerman L, Ziel-van der Made AC, et al. Broadened ligand responsiveness of androgen receptor mutants obtained by random amino acid substitution of $\mathrm{H} 874$ and mutation hot spot T877 in prostate cancer. Int J Cancer 2002; 100: 309317.

[26] Romanel A, Gasi Tandefelt D, Conteduca V, et al. Plasma $A R$ and abiraterone-resistant prostate cancer. Sci Transl Med. 2015; 7: $312 \mathrm{re} 10$

[27] Annala M, Vandekerkhove G, Khalaf D, et al. Circulating tumor DNA genomics correlate with resistance to abiraterone and enzalutamide in prostate cancer. Cancer Discov. 2018; 8: 444-457.

[28] Antonarakis ES, Lu C, Wang H, et al. AR-V7 and resistance to enzalutamide and abiraterone in prostate cancer. N Eng J Med. 2014; 371: 1028-1038.

[29] Tagawa ST, Antonarakis ES, Gjyrezi A, et al. Expression of $\mathrm{AR}-\mathrm{V} 7$ and $\mathrm{ARv}^{567 \mathrm{es}}$ in circulating tumor cells correlates with outcomes to taxane therapy in men with metastatic prostate cancer treated in TAXYNERGY. Clin Cancer Res. 2019; 25: 18801888.

[30] Bernemann C, Schnoeller TJ, Luedeke M, et al. Expression of AR-V7 in circulating tumour cells does not preclude response to next generation androgen deprivation therapy in patients with castration resistant prostate cancer. Eur Urol. 2017; 71: 1-3. 
[31] To SQ, Kwan EM, Fettke HC, et al. Expression of androgen receptor splice variant 7 or 9 in whole blood does not predict response to androgen-axis-targeting agents in metastatic castration-resistant prostate cancer. Eur Urol. 2018; 73: 818-821.

[32] Armstrong AJ, Halabi S, Luo J, et al. The PROPHECY trial: multicenter prospective trial of circulating tumor cell (CTC) AR-V7 detection in men with $\mathrm{mCRPC}$ receiving abiraterone (A) or enzalutamide (E). J Clin Oncol. 2018; 36(15 Suppl): 5004.

[33] Arora VK, Schenkein E, Murali R, et al. Glucocorticoid receptor confers resistance to antiandrogens by bypassing androgen receptor blockade. Cell 2013; 155: 1309-1322.

[34] Puhr M, Hoefer J, Eigentler A, et al. The glucocorticoid receptor is a key player for prostate cancer cell survival and a target for improved antiandrogen therapy. Clin Cancer Res. 2018; 24: 927-938.

[35] Annala M, Struss WJ, Warner EW, et al. Treatment outcomes and tumor loss of heterozygosity in germline DNA repair-deficient prostate cancer. Eur Urol. 2017; 72: 34-42.

[36] Mateo J, Porta N, Bianchini D, et al. Olaparib in patients with metastatic castration-resistant prostate cancer with DNA repair gene aberrations (TOPARP-B): a multicentre, open-label, randomised, phase 2 trial. Lancet Oncol. 2020; 21: 162-174.

[37] Cheng HH, Pritchard CC, Boyd T, et al. Biallelic inactivation of $B R C A 2$ in platinum-sensitive metastatic castration-resistant prostate cancer. Eur Urol. 2016; 69: 992-995.

[38] Szarvas T, Csizmarik A, Szúcs M, et al. Molecular subtypes and perspectives of targeted therapies in prostate cancer. [A prosztatarák molekuláris altípusai és célzott terápiás kilátásai.] Orv Hetil. 2019; 160: 252-263. [Hungarian]

[39] Pal SK, Patel J, He M, et al. Identification of mechanisms of resistance to treatment with abiraterone acetate or enzalutamide in patients with castration-resistant prostate cancer (CRPC). Cancer 2018; 124: 1216-1224.

[40] Wang L, Dehm SM, Hillman DW, et al. A prospective genomewide study of prostate cancer metastases reveals association of Wnt pathway activation and increased cell cycle proliferation with primary resistance to abiraterone acetate-prednisone. Ann Oncol. 2018; 29: 352-360.
[41] Isaacsson Velho P, Fu W, Wanga H, et al. Wnt-pathway activating mutations are associated with resistance to first-line abiraterone and enzalutamide in castration-resistant prostate cancer. Eur Urol. 2020; 77: 14-21.

[42] Bishop JL, Sio A, Angeles A, et al. PD-Ll is highly expressed in enzalutamide resistant prostate cancer. Oncotarget 2015; 6: 234-242.

[43] Graff JN, Alumkal JJ, Thompson RF, et al. Pembrolizumab (Pembro) plus enzalutamide (Enz) in metastatic castration resistant prostate cancer (mCRPC): extended follow up. J Clin Oncol. 2018; 36(15 Suppl): 5047.

[44] Küronya Z, Biró K, Maráz A, et al. The modern treatment of metastatic castration-resistant prostate cancer. [Metasztatikus kasztrációrezisztens prosztatadaganat korszerü kezelése.] Magy Onkol. 2019; 63: 41-50. [Hungarian]

[45] Beltran H, Tagawa ST, Park K, et al. Challenges in recognizing treatment-related neuroendocrine prostate cancer. J Clin Oncol. 2012; 30: e386-e389.

[46] Heck MM, Thaler MA, Schmid SC, et al. Chromogramin A and neurone-specific enolase serum levels as predictors of treatment outcome in patients with metastatic castration-resistant prostate cancer undergoing abiraterone therapy. BJU Int. 2017; 119: $30-37$.

[47] Aggarwal R, Huang J, Alumkal JJ, et al. Clinical and genomic characterization of treatment-emergent small-cell neuroendocrine prostate cancer: a multi-institutional prospective study. J Clin Oncol. 2018; 36: 2492-2503.

[48] Corn PG, Heath EI, Zurita A, et al. Cabazitaxel plus carboplatin for the treatment of men with metastatic castration-resistant prostate cancers: a randomised, open-label, phase 1-2 trial. Lancet Oncol. 2019; 20: 1432-1443. [Correction: Lancet Oncol. 2020; 21: el4.]

\section{"Numquam non miser est qui quod timeat cogitat." (Sosem elégedett, aki csak félelmeire gondol.)}

(Szarvas Tibor dr., Budapest, Üllői út 78/B, 1082 e-mail: sztibusz@gmail.com)

\footnotetext{
A cikk a Creative Commons Attribution 4.0 International License (https://creativecommons.org/licenses/by/4.0/) feltételei szerint publikált Open Access közlemény, melynek szellemében a cikk bármilyen médiumban szabadon felhasználható, megosztható és újraközölhető, feltéve, hogy az eredeti szerző és a közlés helye, illetve a CC License linkje és az esetlegesen végrehajtott módositások feltüntetésre kerülnek. (SID_1)
} 